\title{
TECH-RICH INSTRUCTION: RAISING STUDENTS' AWARENESS AGAINST PLAGIARISM IN ACADEMIC WRITING
}

\author{
Zaini Rohmad \& Dewi Sri Wahyuni \\ Sebelas Maret University \\ zaini_rohmad_solo@yahoo.com \& dewisriwahyuni17@yahoo.co.id
}

\begin{abstract}
Plagiarism is an intolerant action in the circumstances of education; it is stealing or cheating any papers, ideas, and things related to someone's works. This is a harmful offence with academic, professional, legal, and monetary consequences when someone is proved as a plagiarist. Students can be expelled from the class when they cheat colleagues' works; the worst is that the university can retract their certificate of graduation when their manuscripts are investigated and proved as result of copying other works. Regarding to its danger, plagiarism has to be avoided trough establishing curriculum in higher level of education. Teacher and lecturer should provide their lessons, especially in language skills, with awareness of the plagiarism danger to the students. A skill of language that most easily susceptible and detected in plagiarism is writing. Since writing is not a gift skill as listening, students need to learn how to write properly. Simply, when they are not able to rewrite someone's statements with their own wording, students are doing plagiarism. This article reporting at a descriptive qualitative research aimed at describing the teaching method to raise students' awareness toward the danger of plagiarism which is applied by a lecturer in Academic Writing Class of EED - UNS for the academic year 2016. She believes that when the students have awareness in the risks or consequences of plagiarism, they will act for not doing plagiarism in their works. She supports her conventional way of teaching with technology of plagiarism checker. The method of enrichment traditional teaching with technology is known as Tech-Rich Instruction (not blended learning). This Tech-Rich Instruction she applied is successfully raising her students' awareness in the danger of plagiarism and leads to the efforts of avoiding plagiarism in academic writing.
\end{abstract}

Keywords: students' awareness, plagiarism, academic writing, Tech-Rich Instruction

\section{Introduction}

Writing becomes more challenging in recent years. Due to the age of digital technology, information goes to writing format rather than spoken style. People prefer to read information since written information can be easily documented and tracked when readers need to search the sources of information. The demands toward accurate and entertaining information as well as make writers change their style of writing creatively, especially when writers share their information and ideas through social media.

The changes of purpose and style of writing have no impact academically for higher educational institutions. In fact, in universities, writing academically becomes requirement when lecturers and students need to present their ideas. Academic writing is the atmosphere in universities. Journals, text books, research reports, daily papers, even note tak- ing during the lesson are the examples of academic writing. Academic writing is easily recognized through its standart language, format, and style. It has strict roles and rules in the presentation in which people need to consider of those before they start to write in academic manner.

Realizing the important of academic writing, some universities, including Sebelas Maret University (UNS) take actions. There are some programs for lecturers to enhance ability in writing academically, such as journal writing workshop, short course in English academic writing, and coaching clinic in international article writing. Meanwhile, for preparing students with academic writing skills, the departments in the universities provide guideline book that becomes a base to write manuscript or research report. The guideline contains style of writing adopted from recognized writing format style and used internationally 
in some leading countries. Adopting international format style as national academic writing style is simply because the intention of presenting paper or manuscript is for international scope reading. APA (American Psychological Association) is the most writing style adopted by educational institutions, especially in the field of sciences. It provides A-to-Z rules to present written academic paper. Some of departments, especially in language teaching program, design their curriculum coping courses on how to write in academic manner.

English Education Department (EED) as part of Teacher Training and Education Faculty various types of development. As the improvement of Paragraph Development, in the third semester, there is Essay Writing composed with various types of development also. In fourth semester, course of Writing will bring the students to have skill in Academic Writing in which the goal of this course is that students produce a mini proposal for handling research. In the last gradation, the fifth semester, students are learnt on how to make an article based on academic research. Obviously, the ability to produce academic writing for the students in EED is not instantly taught in one semester but the students have to follow some series of Writing courses in the years of their study.

In each level of Writing course, plagiarism remains as crucial issue; therefore, the learning objective developed in each Writing course states that students' works (compositions) are free of plagiarism or have less than $30 \%$ of plagiarism mark. Plagiarism is an offense action of stealing one's idea or work. The action of plagiarism does not take impact on material damage or lost but it gives worst impact on one's intellectual violation. The punishments for this action can cause the doers loss their academic recognition, social excommunicated and potentially monetary lost.

Due to the importance of academic writing which is free from plagiarism or has less than $30 \%$ plagiarism, the lecturers of EED need to apply such method of teaching Writing which makes students aware on plagiarism and do not do plagiarism in their writing. The researchers, therefore, conducted a descriptive research which was aimed at describing on what teaching instruction used by lecturers in Academic Writing class to make students have sense of awareness toward the danger of plagiarism and how they apply it as classroom instruction.

\section{Method}

In gaining the research's objective, the researchers worked with descriptive research. Descriptive research is an effort to describe phenomenon with its aspects and characteristics and/or behaviors of sample from intended population. In describing the instruction of teaching used by lecturers to raise students' awareness on the danger of plagiarism, the researchers made no control on classroom interaction. It viewed the classroom with its natural teaching and learning process. Borg and Gall (1898) classified one of focuses on descriptive educational as description on natural and man-made phenomenon in classroom intended to education practitioners or policy makers. Stepping out the procedure of descriptive research, there are description, explanation, and validation the findings. To collect the data, the researchers used in-class observation, in-depth interview with the lecturers, and document analysis. In the efforts of analyzing collected data, there was an interactive model analysis, a method of qualitative data analysis as proposed by Milles and Huberman (1992).

\section{Findings \\ Classroom setting}

This research took one class of Academic Writing classes handled in the fourth semester as sample to search data. Academic Writing class is one of Writing serial classes in EED, Teacher Training and Education Faculty, Sebelas Maret University. Academic Writing course is designed to make students be able to compose a mini research proposal in the form of the first and second chapters, which is free from plagiarism or has $30 \%$ free from plagiarism, based on mostly acceptable writing format style, APA, which is combined with UNS guideline in academic writing. The learning materials for reaching out the objective of academic writing learning are developing critical thinking in writing, differentiate fact and opinion, finding references, selecting key points in some articles, avoiding plagiarism in writing by citation, summarizing, and paraphrasing, constructing theory from some extended theories, elaborating background of research embedded with research questions, 
and developing supporting literature review. Simply, there are two focuses in teaching academic writing; (1) leading students to have ability in writing academically and (2) encouraging students for not doing plagiarism in their writing.

Each class in Academic Writing contains 14 until 16 students. It is a small scale class since teaching writing is not easy when it is done within large number students in one class. However, big class for teaching writing is also possible by which teacher or lecturer needs more efforts for doing so.

\section{Lecturer's Instruction}

In the effort for integrating two focuses in academic writing class; that are (1) leading students to have ability in writing academically and (2) encouraging students for not doing plagiarism in their writing, the lecturer applied certain instruction in teaching. Instruction means as intended direction in the learning process. Joyce, Weil, and Calhoun (2003) classified instruction into 4 categories. They are behavioral systems, information processing, personal development, and social interaction. To choose which instruction is best applied; teachers have to consider the desired goal of learning process.

Elaborating goal and focuses of teaching academic writing, the lecturer adopts instruction containing some steps. In the first step, lecturer gives learning objectives and lead students' orientation to lesson which was done in the first meeting. Lecturer describes the content of academic writing course including short description of the course, range of learning materials, sources of learning, learning activities, scoring rubric for evaluation, and learning rules for students in class. The materials are given from the basic of academic writing up to how to create mini proposal. The knowledge of critical thinking in writing is also given to students. Relating to act of plagiarism, lecturer presents the definition, danger, and strategies to avoid plagiarism. In the second step, the lecturer reviews some conditions in academic writing course, for examples: the students have to download APA ebook and academic writing guideline issued by UNS Teacher and Training Education Faculty, the students should read some articles in international journals and make summaries from those articles (these activities have aims for students to decide the topic of mini thesis proposal and practice the writing strategies in avoiding plagiarism). In the third step, lecturer presents new materials connecting to academic writing, such as critical thinking on writing that can be framed on article journal summaries (in the first part of this summary, students describe the article as the way it is; they are only picturing the content of the article using their own wording; and in the second part, students give their evaluation by using their critical thinking toward the article they read), strategies in avoiding plagiarism (how to cite, paraphrase, summary, and do referring in text or out text). In the fourth step, lecturer conducts learning exploration toward the material being studied. In this exploration, lecturer gives some examples of journal articles and thesis proposals to the students. She asks students to analyze the writing format, outline, content of the samples. Based on result of analysis, the students can evaluate and decide which of the samples is good, readable, and manageable. In the fifth step, lecturer provides time to individual practice. In this section, students are guided to choose topic that will become their subject in writing mini research proposal. This topic is individually chosen based on students' interest (which can be seen from the articles they read and summarize). Students have to practice strategies in avoiding plagiarism in their article journal summaries and mini research proposal. In the sixth step, lecturer gives review students article journal summaries including correction, feedback, and scoring. There three aspects being reviewed in students' summaries; they are grammatical rules, content relating to descriptive writing and critical writing, and plagiarism. The lecturer reviews the content conventionally. She does by reading it carefully and comparing the original article with summary version.

In checking grammatical rules and plagiarism, lecturer applies Turnitin checker program. Turnitin is a detector program for checking plagiarism in writing. It was established in 1997 in USA. As a web-based program, Turnitin offers its commercial services to clients, especially, those who work in education institution. Under the license of Turnitin, institutions can open hundreds of web-based classes. When the class is opened, the educators are able to check students submitted papers which are automatically compared to existing database and world-wide 
websites in order to locate plagiarism. Turnitin offers various and advanced interactions which are claimed can make learning better and easier because it provides all responds in a dialog window. There are three advantages of using Turnitin as part of classroom instruction. (1) It provides integration of sources material taken from around the world digital database compared to students' collected papers or articles. The machine of Turnitin is automatically checking the students' originality and highlights the suspected writing and completed with the sources of citations or references. When students are found they are suspected to act plagiarism, they will take more efforts to greener their writing. It means that they are challenged to use their critical thinking in their writing. (2) Turnitin is effective and efficient in giving feedback to students' worksheet through Feedback Studio. This studio provides scoring rubric, grammatical code that can be added on purposively, and dialog tool to communicate with students. The students will find their error and mistakes in grammar by recognizing the grammatical code and comments given by the lecturer in their paper. It is absolutely saving energy and time for lecturer to correct and give feedback in students' paper. (3) The Feedback Studio also provides standard-based testing and rubric for evaluating and scoring students' paper. This will give positive affect to students' outcomes, because they know that they are treated in equal by lecturer via scoring rubric in Feedback Studio.

\section{Students' Perception on Plagiarism}

Students in Writing Academic class are assigned to make summaries on articles found in e-journals. There are two parts in writing summary; (1) students have to describe the content of article or picturing articles the way it is and (2) they have to give comment about the article by using their critical thinking and background knowledge. During the semester, students have to collect 8 summaries in the same topic and different articles. They are informed that the summaries will be scored based on originality (dealing with plagiarism), grammatical order, referencing and citation (based on UNS's guideline plus APA style), and content (whether it is equal to origin or not). They are also informed how to access Turnitin and how to send their summaries.

In the first summary collection, the stu- dents have under average score in their works. The mark of plagiarism in Feedback Studio of Turnitin tends yellow to red. The statistic shows that almost $95 \%$ of students doing plagiarism. Based on the interview, it is revealed that students' perception toward plagiarism was poor (including how to use APA style and UNS's guideline). They did not aware about the danger of plagiarism. Besides, they did not apply seriously the strategies for avoiding plagiarism in writing. Their summaries are full of grammatical code showing error or mistake. They did not realize that Turnitin Feedback Studio will give detail correction and scoring. In the second and third attempts, their perception toward plagiarism and Turnitin moved to better level. They did their assignment seriously. They consulted with UNS guideline and APA writing style to deal with how to make citation and reference. Although the indicator of plagiarism in Turnitin changed greener, it was found that their descriptive writings did not framing the original yet. They needed more efforts when writing the content of the original articles. What they have to improve was their ability in reading comprehensively so that they can describe the writer's real intention. Another thing should be improved was their knowledge on how to write correctly. Some students did mistake and error in using proper to be and verb relating to subject.

\section{Discussion}

\section{The Use of Technology-Rich Instruction}

Based on the data finding, it can be interpreted that (1) lecturer of Academic Writing class uses direct instruction as the approach of her classroom teaching. The use of approach has broader sense than applying certain method. The use of direct instruction is indicated from the steps of teaching. First, the lecturer gives learning objectives and lead students' orientation to lesson which was done in the first meeting. Second, the lecturer reviews some conditions in academic writing course. Third, lecturer presents new materials connecting to academic writing. Fourth, lecturer conducts learning exploration toward the material being studied. Fifth, lecturer provides time to individual practice. Sixth, lecturer gives review in which the last step of Slavin's version is put in this step. These steps are corporate with the principles of direct instruction as proposed by Slavin (1994). Slavin's princi- 
ples on direct instruction are (1) stating learning objectives and orient students to lesson; (2) reviewing prerequisites; (3) presenting new material; (4) conducting learning probes; (5) providing independent practice; (6) assessing performance and provide feedback; (7) providing distributed practice and review The direct instruction is not focused on students as the center of teaching process but it is a teacher domination in classroom activities. Students are given a free phase when they have to decide what topic should write as their mini proposal of thesis. Another result of finding is to raise maximal awareness on the danger of plagiarism and minimize plagiarism in students' writing, the application of direct instruction is supported by the use of digital technology (in this case is Turnitin).

The combination of using direct method and digital based technology in teaching Academic Writing is included into a model called as Tech-Rich Instruction or Technology-Rich Instruction. This instruction is basically integrating a classical teacher act in class with technology supports. The term technology which is used in this instruction has broader sense rather than digital based technology; such as: teacher may use electronic whiteboards to visualize her explanation, or in simple way, the use of LCD to deliver the material of teaching. The use of technology can also go to sophisticate technology; the use of virtual reality as the example. These technologies may enrich students' learning activities and experience, but do not shift direct instruction given in class. The teacher or lecturer holds and controls the classroom activities. Technology-Rich Instruction is absolutely different from Blended Learning (Hybrid Learning) in the way that in Tech-Rich Instruction, technology does not replace face-to-face instruction in class. There are some concepts of Tech-Rich Instruction; (1) technologies are functioned as support and supplement toward teaching activities; (2) technologies used are under management of teacher; (3) students are only allowed to apply the technologies proposed in class; (4) the use of technologies are documented in lesson plans; and (5) this instruction can only apply in traditional class.

Finally, the use of Turnitin to support classroom instruction in Academic Writing class brings positive impact toward students' awareness on avoiding the danger of plagiarism. Students take efforts in avoiding plagia- rism on their paper or article. It can be shown from the last summary collection, the indicator of plagiarism was $90 \%$ green. It can be interpreted that students were not doing plagiarism in their work. They could manage on how to avoid plagiarism in writing. From the interview, 92\% students realized that doing plagiarism is a crime offense on others' thinking right. They said that they did want others stealing their idea too. They become aware on plagiarism especially on its danger. The use of Turnitin as plagiarism checker program to their works helps them in rising the awareness on the danger of plagiarism also in making it.

\section{Conclusion}

Based on the findings, it is proved that more $90 \%$ of the students have realized that doing plagiarism is a crime offense on others' rights. It is actually a stealing act; They do not want others stealing their idea too. They become aware on the danger of plagiarism. The use of Turnitin as plagiarism checker to their works helps them in rising the awareness. In their final task, based on the checker, $90 \%$ of their works are free of plagiarism, meaning that they really practice anti-plagiarism in their works.

\section{Ackowledgment}

In finishing this research, the researchers would state great thanks for (1) the institution, especially English Education Department of Teacher Training and education Faculty, Sebelas Maret University, (2) lecturers of Academic Writing Classes in EED, and (3) students in Academic Writing class.

\section{References}

Bloom, B. (1976). Human characteristics and school learning. New York: McGraw-Hill.

Borg, W. R., \& Gall, M. D. (1989). Educational

research. An introduction (5th ed.). White Plains, NY Longman

Gagne, R. (1977). The conditions of learning (3rd ed.). New York: Holt, Rinehart, \& Winston.

Gagne, R., \& Briggs, L. (1979). Principles of instructional design (2nd ed.). New York: Holt,

Rinehart, \& Winston. Groff, S. Jennifer. 2013. OECD: Innovative Learning Environments project: Technology- Rich Innovative Learning Environments.

Joyce, B., \& Weil, M., \& Calhoun, E. (2003). 
Models of teaching (7th ed.). Boston: Allyn \& Bacon.

Maxwell, Clifford in What blended learning is and isn't written on March 4, 2016 in https://www.blendedlearning.org/ what-blended-learning-is-and-isnt/

Miles, Mathew B dan Huberman, Michael A, Analisis Data Kualitatif. (Diterjemahkan oleh Tjejep Rohendi Rohidi), Univesitas Indonesia. (UIPress), Jakarta, 1992.

Rosenshine, B. (1995). Advances in research on instruction. The Journal of Educational Research, 88(5), 262-268. https:// www.mindflash.com/elearning/whatis-blended-learning 